\title{
The Development of Sociology Teaching Materials Based on Articulate Storyline to Improve Students' Critical Thinking Skill
}

\author{
Yuni Sudiasih $^{1}$, Risma Margaretha Sinaga ${ }^{2}$, Sugeng Widodo ${ }^{3}$ \\ Master of Social Science, Faculty of Teacher Training and Educational Sciences, Lampung University, \\ Bandar Lampung, Indonesia ${ }^{123}$
}

\begin{abstract}
This research purpose to develop the Sociology teaching materials based on articulate storyline and test the effectiveness of its use to improve students' critical thinking skills. This research and development used the Borg and Gall model. The development stage was simplified to the sixth stage, such as: 1) research and information collection, 2) planning, 3) develop preliminary form of product, 4) preliminary field testing, 5) main product revision, and 6) main field testing. The subjects of preliminary field testing consisted of material experts, media experts, linguists, and users (individuals, small groups, and medium groups). Main field testing was conducted on students of class XI IPS 4 shift A as the experimental group. The effectiveness of using articulate storyline-based Sociology teaching materials to improve students' critical thinking skills was known by comparing the critical thinking skills of students in class XI IPS 4, shift A as the experimental group and shift B as a control group. Data about product feasibility were collected by using a questionnaire technique, while data on critical thinking skills were collected by using a test technique and analysed quantitatively by using the gain normality test. The results showed that: 1) the articulate storyline-based sociology teaching materials that was developed by using the Borg and Gall model were declared suitable for use in sociology learning. 2) The use of articulate storyline-based sociology teaching materials is quite effective in improving students' critical thinking skills with a normalized gain value of $60.30 \%$.
\end{abstract}

Keywords: articulate storyline-based teaching materials, critical thinking skills, sociology learning.

\section{INTRODUCTION}

The critical thinking skills can be used as a guide for someone in dealing with various problem. By having critical thinking someone can provide basic explanations, build basic skills, conclude, make further explanations, and set strategies and tactics. Critical thinking skills do not grow by themselves, but must be developed through an educational process [1]. Educational reform considers the importance of making various efforts in building wisdom, making students aware of thinking, having critical thinking, and being able to judge the truth of something [2]. Critical thinking skills can also be used to test opinions or ideas, including the process of consideration or thinking that is based on the opinions submitted and can be accounted for [3]. Critical thinking skills can be used to develop reflective and logical thinking through the process of assessing, drawing conclusions, giving opinions, formulating questions, making plans, and defining terms [4].

The critical thinking skill of students in the class of XI IPS SMAN 1 Tumijajar can be seen from the table below.

TABEL I THE ACHIEVEMENT OF STUDENTS' CRITICAL THINKING INDICATORS

\begin{tabular}{|c|c|c|c|c|c|c|c|c|c|}
\hline \multirow{2}{*}{\multicolumn{2}{|c|}{ Indicators }} & \multicolumn{2}{|c|}{ XI IPS 1} & \multicolumn{2}{|c|}{ XI IPS 2} & \multicolumn{2}{|c|}{ XI IPS 3} & \multicolumn{2}{|c|}{ XI IPS 4} \\
\hline & & $\mathrm{f}$ & $\%$ & $\mathrm{f}$ & $\%$ & $\mathrm{f}$ & $\%$ & $\mathrm{f}$ & $\%$ \\
\hline 1. & Provide basic explanation & 3 & 8,82 & 3 & 9,68 & 2 & 6,06 & 2 & 6,06 \\
\hline 2. & Build basic skill & 6 & 17,65 & 4 & 12,90 & 5 & 15,15 & 6 & 18,18 \\
\hline 3. & Conclude & 1 & 2,94 & 2 & 6,45 & 2 & 6,06 & 5 & 15,15 \\
\hline 4. & Make further explanation & 5 & 14,71 & 5 & 16,13 & 4 & 15,15 & 2 & 6,06 \\
\hline 5. & Strategies and tactics & 10 & 29,41 & 7 & 22,58 & 10 & 30,30 & 6 & 18,18 \\
\hline \multicolumn{2}{|c|}{ Average of achievement indicators } & \multicolumn{2}{|c|}{$14,71 \%$} & \multicolumn{2}{|c|}{$13,55 \%$} & \multicolumn{2}{|c|}{$14,55 \%$} & \multicolumn{2}{|c|}{$12,73 \%$} \\
\hline
\end{tabular}

Based on Table 1, it can be interpreted that the critical thinking skills of students at SMAN 1 Tumijajar, Tulang Bawang Barat Regency, Lampung Province were still needed to be improved. The lowest indicator achievement was the conclusion indicator $(7.65 \%)$, and the highest was strategies and tactics $(25.12 \%)$. The students from class XI IPS 4 had 


\section{International Advanced Research Journal in Science, Engineering and Technology \\ Impact Factor 7.105 $\div$ Vol. 9, Issue 2, February 2022 \\ DOI: 10.17148/IARJSET.2022.9201}

the lowest average achievement compared to the other classes. Therefore, the product developed in this research was focused on improving critical thinking skills of the students in class of XI IPS 4.

Teachers were required to do many things to overcome the problem of students' low critical thinking. One of them was to develop teaching materials based on articulate storylines. Articulate storylines can be used to create interactive learning tools created by combining text, images, graphics, sound, animation, and video and the results could be accessed by web (html5) or in the form of applications and can be run by used laptops, tablets, smartphones and mobile phones [5]. The use of the teaching materials was expected to improve students' critical thinking skills, especially in learning sociology at SMAN 1 Tumijajar, Tulang Bawang Barat Regency, Lampung Province.

\section{MATERIALS AND MethodS}

\section{A. Materials}

Critical thinking is reasonable and reflective thinking that focuses on making decisions about what to believe and do [6]. The ability to think critically will be beneficial to someone in deciding (judging) a matter and producing an interpretation, analysis, evaluation, inference, explanation, and self-regulation which is the basis for decision making [7]. Critical thinking skills in this study are interpreted as thinking skills that students must have to be able to solve their life problems by identifying any information they receive, evaluating and conveying it systematically and being able to express opinions in an organized manner. The indicators used to measure critical thinking skills such as: 1) provide basic explanations, 2) build basic skills, 3) conclude, 4) make further explanations, and 5) strategies and tactics [6].

According to Lewis [8], teaching materials are defined as the spectrum of educational materials used by teachers in the classroom that support the achievement of learning objectives as set out in the lesson plan. Teaching materials in this study are defined as learning components used by educators as learning materials that are systematically arranged and useful for students to develop various competencies, both knowledge, skills, and attitudes. The teaching-based materials developed in this research are teaching materials in the form of interactive multimedia learning developed using the articulate storyline software. Interactive multimedia teaching materials are defined as teaching materials that combine several learning media and are packaged (programmed) in an integrated and interactive way to present certain learning messages (knowledge, skills, and attitudes) [9].

\section{B. Method}

This research and development used the Borg and Gall model with the simplification of six research stages, such as: 1) research and information collection, 2) planning, 3) develop preliminary form of product, 4) preliminary field testing, 5) main product revision, and 6) main field testing. Questionnaires were used to obtain data on the feasibility of empirical and theoretical Sociology teaching materials based on articulate storylines. The feasibility of the product being developed was carried out on material experts, media experts, linguists, and also tested on users, either individually, in small groups, or in medium groups. Measurement of the questionnaire used Likert scale.

The effectiveness of using development products to improve critical thinking skills was tested through a quasiexperimental research design with a non-equivalent control group design model. Experimental group consist of the students from group A on the class of XI IPS 4. Whereas the control group consist of the students from group B on the class of XI IPS 4. The product effectiveness tested with the quasi-experimental involved students from experimental group who were given treatment in the form of teaching materials that had been developed, and the control group which was treated in the form of power point-based teaching materials. The test technique was used to collect data on students' critical thinking skills. The research instrument was in the form of 20 multiple choice questions.

\section{RESULT AND DISCUSSION}

A. Development of Sociology Teaching Materials Based on Articulate Storyline

The steps of developing Sociology teaching materials based on the articulate storyline in this research and development used the Bord and Gall model and were simplified into six steps.

1) Research and information collection.

Preliminary study was carried out to identify potential could be developed and problems could be solved. The information was obtained that students needed the teaching materials could be accessed using android and used in sociology learning during the Covid-19 Pandemic. The teaching materials were needed by students contain various facts and real problems that occur in society. One of them related to the fact of social conflicts especially happened during the Covid-19 pandemic. 


\section{International Advanced Research Journal in Science, Engineering and Technology \\ Impact Factor 7.105 ㄷ Vol. 9, Issue 2, February 2022 \\ DOI: 10.17148/IARJSET.2022.9201}

2) Planning.

The planning was carried out by determining: 1) basic competencies were taken from the Regulation of the Minister of Education and Culture of the Republic of Indonesia Number 37 of 2018, "Analyz social conflicts and how to provide responses to conflict resolution for the creation of a peaceful life in society", 2) formulated indicators of competency achievement, 3) developed teaching plans and implementation, 4) developed research instruments to measure students' critical thinking skills, 5) developed learning material, that was social conflicts and the resolution efforts, 6) designed evaluations, and 7) made flowcharts.

3) Develop preliminary form of product.

The teaching materials developed were interactive learning multimedia. Sociology teaching materials in the form of interactive multimedia learning social conflict materials and their resolution efforts were developed into three parts. Part one consisted of sub-materials on the nature of social conflict, theories of social conflict, and the factors that cause social conflict. Part two consisted of sub-materials on the classification of social conflicts. Part three consisted of sub-materials on the impact of social conflict, violence, and efforts to resolve social conflicts. The division of teaching materials into three parts was intended that the product can accommodate the content or material content more optimally.

4) Preliminary field testing.

The preliminary field testing involved three experts. They were material experts, media experts, and linguists. Material validation aims to get a decent product on aspects: 1) the suitability of the material with core competencies and basic competencies, 2) the accuracy of the material, 3) the up-to-date ness of the material, 4) encouraging curiosity, and 5) ease of use and understanding. Based on the assessment of material experts, the product developed got an average score of 4.37 or $90.48 \%$ or was categorized as a very suitable for use. Media validation aims to get a decent product in terms of display and programming. Based on the assessment of media experts, the product developed got an average score of 3.36 or was categorized as suitable for use. Language validation aims to get a decent product on aspects: 1) straightforward, 2) communicative, 3) dialogical and interactive, 4) conformity to the development of students, 5) conformity with language rules, and 6) use of terms, symbols, and icons. Based on the assessment of linguists, the product developed got a score of 4.38 or $87.69 \%$ with a very decent category.

Preliminary field testing was also carried out on users. The product assessment at the preliminary field testing in the user group can be seen in the following chart.

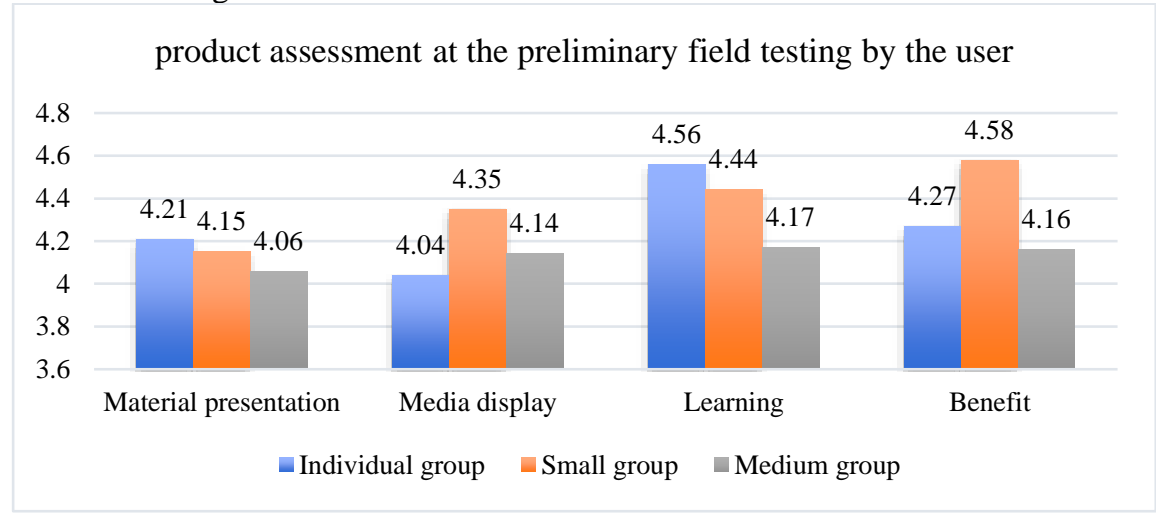

Based on the chart, it can be seen that the product developed got an average score of 4.26 or with a very suitable category for use in Sociology learning.

5) Main product revision.

The product of teaching materials in the form of interactive learning multimedia was revised based on suggestions and opinions given by material experts, media experts, linguists, and users. In the following, comments/suggestions and the results of improvements are presented in accordance with these comments/suggestions. Materials experts argue that the presentation of material on the developed product can be expanded into several parts so that it can further bring up sociological idioms. Based on this suggestion, the teaching materials were further developed into several parts. Part one with sub-materials on the nature of conflict, conflict theories, and the factors that cause social conflict. Part two contains sub-materials on the classification of social conflicts, and part three contains sub-materials on the impact of social conflict, violence, and efforts to resolve conflicts.

Media experts provide suggestions for revisiting the importance of images and animations contained in the product. The layout and appearance of the menu must also adjust to the development of product users. Linguists provided suggestions to pay more attention to the use of language and grammar so that the resulting product didn't violate linguistic provisions. 


\section{International Advanced Research Journal in Science, Engineering and Technology \\ Impact Factor $7.105 \div$ Vol. 9, Issue 2, February 2022 \\ DOI: 10.17148/IARJSET.2022.9201}

6) Main field testing

The field trial purposed to determine the effectiveness of using articulate storyline-based teaching materials to improve students' critical thinking skills in Sociology learning on the class of XI IPS 4 SMAN 1 Tumijajar. The main field trial was conducted on the experimental group using a non-equivalent control group design research design. The experimental group used teaching materials in the form of development products, while the control group used teaching materials based on power point. There was a test carried out before giving treatment, and a final test after being given treatment.

Technology was no longer to blame as it was a few years ago. Technology is now a friend for anyone, including teachers and students in order to support the implementation of learning activities. Teaching critical thinking skills were be needed because it will lead to how a person makes decisions and solves various kinds of problems he faces. As the study of Oliver and Utermohlen quoted by Mahebub Sahana that the students were able to use technology to absorb large information that must be filtered so that they can think actively in receiving various kinds of information. Students need to "develop and effectively apply critical thinking skills to their academic studies, to the complex problems they will face, and to the critical choices they will be forced to make as a result of the information explosion and other rapid technological changes [10]. Content that will be used to carry out learning activities and this is in line with Yildirim and Kiray's opinion that Teachers should determine and consider the content to be stored. The reason that the related content is required for exams or will be used after graduation may not interest students. In this context, the content should be creative and meaningful which increases students' sense of awareness and can also be used in real life [11].

The study uses the view of Constructivist Learning Theory, which states that knowledge is an individual's acquisition through active involvement in the learning process. Based on the Constructivist Learning Theory, students must find and transform complex information by themselves, checking new information with old rules and revising it if the rules are no longer appropriate. The demands on constructivist theory lie in solving a problem in the learning provided by the teacher. The activeness of students in the learning process is the main foundation in constructivist theory. Sociology teaching materials developed using articulate storyline software are expected to assist students in finding and transforming various information and problems they find to find solutions to the problem. As previously discussed, MPI's teaching materials, which were developed using an articulate storyline, also contain cases, facts, and problems surrounding social conflicts that occurred during the Covid-19 pandemic.

Based on Thorndike's Connectionism Learning Theory proposed by Edward Lee Thorndike quoted by Simanjuntak [12], learning is an event of forming associations between events called stimulus (S) and response (R). Stimulus is a change from the external environment which is a sign to activate the organism to react or act while the response from is any behaviour that is caused by the stimulus. The articulate storyline-based Sociology teaching materials developed in this study are expected to be used as a stimulus for students to carry out the learning process. Students are expected to be happy to learn because the stimulus used is in accordance with the development and needs, so that there is a connection or relationship between multimedia as a stimulus and student responses that can improve critical thinking skills.

B. The Effectiveness of Using Sociology Teaching Material Based on Articulate Storyline to Improve Students' Critical Thinking Skills

The effectiveness of using articulate storyline-based sociology teaching materials to improve students' critical thinking skills is carried out through the application of quasi-experimental research with a non-equivalent control group design model. The experimental group was given treatment in sociology learning using a product that had been developed, while the control group used teaching materials based on power point. Before being given treatment, each group was given a pre-test once. After giving the treatment, each group was given a final test. The questions used in the initial and final tests consist of 20 multiple choice questions that have been previously validated and declared valid. The results obtained by students in the initial and final tests can be used as a reference to determine student achievement on indicators of critical thinking skills.

The results of the initial and final tests in the experimental group and control group are presented in Table 2 below.

TABEL II THE RESUlT OF PRE-TEST AND POST-TEST

\begin{tabular}{|c|c|c|c|c|c|c|c|c|}
\hline \multirow{3}{*}{ Indicators } & \multicolumn{4}{|c|}{ Result of Pre-test } & \multicolumn{4}{|c|}{ Result of Post-test } \\
\hline & \multicolumn{2}{|c|}{$\begin{array}{l}\text { Experimental } \\
\text { group }\end{array}$} & \multicolumn{2}{|c|}{$\begin{array}{l}\text { Control } \\
\text { group }\end{array}$} & \multicolumn{2}{|c|}{$\begin{array}{l}\text { Experimental } \\
\text { group }\end{array}$} & \multicolumn{2}{|c|}{ Control group } \\
\hline & $\mathrm{f}$ & $\%$ & $\mathrm{f}$ & $\%$ & $\mathrm{f}$ & $\%$ & $\mathrm{f}$ & $\%$ \\
\hline 1. $\quad$ Provide basic explanation & & & & & & & & \\
\hline Low $\quad: 0-59$ & 12 & 70,59 & 12 & 75,00 & 2 & 11,76 & 5 & 31,25 \\
\hline Medium : $60-75$ & 3 & 17,65 & 1 & 6,25 & 4 & 53,53 & 1 & 6,25 \\
\hline
\end{tabular}




\section{International Advanced Research Journal in Science, Engineering and Technology}

Impact Factor 7.105 $\div$ Vol. 9, Issue 2, February 2022

DOI: 10.17148/IARJSET.2022.9201

\begin{tabular}{|c|c|c|c|c|c|c|c|c|}
\hline \multirow{3}{*}{ Indicators } & \multicolumn{4}{|c|}{ Result of Pre-test } & \multicolumn{4}{|c|}{ Result of Post-test } \\
\hline & \multicolumn{2}{|c|}{$\begin{array}{l}\text { Experimental } \\
\text { group }\end{array}$} & \multicolumn{2}{|c|}{$\begin{array}{l}\text { Control } \\
\text { group }\end{array}$} & \multicolumn{2}{|c|}{$\begin{array}{l}\text { Experimental } \\
\text { group }\end{array}$} & \multicolumn{2}{|c|}{ Control group } \\
\hline & $f$ & $\%$ & $\mathrm{f}$ & $\%$ & $\mathrm{f}$ & $\%$ & $\mathrm{f}$ & $\%$ \\
\hline High $\quad: 76-100$ & 2 & 11,76 & 3 & 18,75 & 11 & 64,71 & 10 & 62,50 \\
\hline Jumlah & 17 & 100,00 & 16 & 100,00 & 17 & 100,00 & 16 & 100,00 \\
\hline Build basic skill & & & & & & & & \\
\hline$: 0-59$ & 13 & 76,47 & 10 & 62,50 & 6 & 35,29 & 7 & 43,75 \\
\hline Medium : $60-75$ & 4 & 23,53 & 4 & 25,00 & 3 & 17,65 & 5 & 31,25 \\
\hline High $: 76-100$ & 0 & 0,00 & 2 & 12,50 & 8 & 47,06 & 4 & 25,00 \\
\hline Jumlah & 17 & 100,00 & 16 & 100,00 & 17 & 100,00 & 16 & 100,00 \\
\hline Conslude & & & & & & & & \\
\hline Low $\quad: 0-59$ & 10 & 58,82 & 5 & 31,25 & 5 & 29,41 & 4 & 25,00 \\
\hline Medium : $60-75$ & 5 & 29,41 & 7 & 43,75 & 1 & 5,88 & 5 & 43,75 \\
\hline High $\quad: 76-100$ & 2 & 11,76 & 4 & 25,00 & 11 & 64,71 & 7 & 31,25 \\
\hline Jumlah & 17 & 100,00 & 16 & 100,00 & 17 & 100,00 & 16 & 100,00 \\
\hline Make further explanation & & & & & & & & \\
\hline Low $\quad: 0-59$ & 14 & 82,35 & 13 & 81,25 & 6 & 35,29 & 12 & 75,00 \\
\hline Medium : $60-75$ & 0 & 0,00 & 0 & 0,00 & 0 & 0,00 & 0 & 0,00 \\
\hline High $\quad: 76-100$ & 3 & 17,65 & 3 & 18,75 & 11 & 64,71 & 4 & 25,00 \\
\hline Jumlah & 17 & 100,00 & 16 & 100,00 & 17 & 100,00 & 16 & 100,00 \\
\hline Strategies and tactics & & & & & & & & \\
\hline Low $\quad: 0-59$ & 8 & 47,06 & 12 & 75,00 & 4 & 23,53 & 10 & 62,50 \\
\hline Medium : $60-75$ & 5 & 29,41 & 4 & 25,00 & 3 & 17,65 & 5 & 31,25 \\
\hline High $: 76-100$ & 4 & 23,53 & 0 & 0,00 & 10 & 58,82 & 1 & 6,25 \\
\hline Total & 17 & 100,00 & 16 & 100,00 & 17 & 100,00 & 16 & 100,00 \\
\hline
\end{tabular}

Source: Research data, 2021

Based on the results of the pre-test and post-test in the experimental group as well as the effectiveness of increasing critical thinking skills in the experimental group, it was obtained information that the lowest pre-test score in the experimental group was 35 and the highest was 85 , however, when viewed from the average value obtained only in the range of 54.41 in the "unfinished" category. After being given learning treatment using articulate storyline-based teaching materials, there was an increase in the acquisition of post-test scores. The lowest post-test score is 60 and the highest is 100. The table also describes the effectiveness of increasing critical thinking skills through the calculation of the percent $\mathrm{N}$-gain score, with the lowest score of $36.36 \%$ and the highest $100 \%$. The average value of $\mathrm{N}$-gain percent in the experimental class is $60.3001 \%$. This can be interpreted that the use of articulate storyline-based teaching materials in Sociology learning can be categorized as "quite effective" in improving students' critical thinking skills. In the control group which was given teaching materials in the form of Ppt, the average $\mathrm{N}$-gain score was 24.1401 or $24.14 \%$ which was included in the "ineffective" category. Obtained a minimum N-gain score of 7.69 and a maximum of 50.00.

The effectiveness of using articulate storyline-based Sociology teaching materials to improve critical thinking skills can be seen from the achievement of critical thinking indicators. Indicators providing basic explanations were successfully achieved by $94.12 \%$ of respondents with an average score of 85.29 . The indicator of building basic skills was achieved by $64.71 \%$ of respondents with an average value of 76.47 . The indicator concludes that $70.59 \%$ of respondents have achieved success with an average value of 77.21. The indicator for making further explanations was successfully achieved by around $64.71 \%$ with the average score that could be achieved was 79.41 . Indicators of strategy and tactics can be achieved by $58.82 \%$ of respondents with an average value of 76.47 .

It was one way for teachers to be creative in creating learning materials according to the learning needs of students. A teacher played an important role in being creative and innovating, creating various teaching materials and applying innovative learning models. As the research findings of Prastowo [13] that an educator was required to be creative in compiling teaching materials that are innovative, varied, interesting, and impress the students. The learning process became fun and got the results as planned. We can say that the respondents, in this case were students in the experimental class, still had the difficulty deciding an action to take in answering various problems, but they had very good abilities to analyse arguments. 


\section{International Advanced Research Journal in Science, Engineering and Technology \\ Impact Factor $7.105 \div$ Vol. 9, Issue 2, February 2022 \\ DOI: 10.17148/IARJSET.2022.9201}

The Covid-19 pandemic gave an impact on the effectiveness of Sociology learning. It was a challenge for Sociology teachers to present various ways to create effective learning even though with various limitations. In this study, researchers tried to do various things so as to create a maximum learning process. The development material teaching in the form of multimedia of interactive learning based on articulate storyline software was expected to be a solution to create maximum Sociology learning during the Covid-19 pandemic. One of the issues that this research intends to raise a problem related to students' critical thinking skills during the Covid-19 pandemic.

\section{CONCLUSION}

The development of Sociology teaching material based on articulate storyline in this study used the Borg and Gall model. The development steps consist of: 1) research and information collection, 2) planning, 3) develop preliminary form of product, 4) preliminary field testing, 5) main product revision, and 6) main field testing. The development product was declared very feasible $(4,08)$ according to media experts, material experts, and linguists. The product was declared very feasible $(4,26)$ through the user trials consisted of individual groups, small groups, and medium groups, and can be used in sociology learning.

The use of development products in Sociology learning in the experimental group was declared quite effective ( $\mathrm{n}$-gain = $60,30 \%$ ) to improve students' critical thinking skills. Meanwhile, in the control group that used the teaching material based on power point in Sociology learning was ineffective to improve students' critical thinking skills. It was known from the average of n-gain score of $24,14 \%$.

\section{REFERENCES}

[1] S. Zubaidah, "Mengenal 4C: Learning and Innovation Skills Untuk Menghadapi Era Revolusi Industri 4.0," in 2nd Science Education National Conference, 2018, no. Oktober, hal. 1-18.

[2] N. Mahapoonyanont, R. Krahomwong, D. Kochakornjarupong, dan W. Rachasong, "Critical thinking abilities assessment tools : reliability generalization,” Procedia Soc. Behav. Sci., vol. 2, no. 2, hal. 434-438, 2010, doi: 10.1016/j.sbspro.2010.03.038.

[3] A. Purnomo dan Suprayitno, "Peningkatan Kemampuan Berpikir Kritis Siswa dengan Penerapan Model Pembelajaran Kooperatif Tipe TPS (Think Pair Share) dalam Pembelajaran,” J. Penelit. Pendidik. Guru Sekol. Dasar, vol. 1, no. 2, hal. 1-9, 2013.

[4] M. Lipiec, 'Developing and Measuring Students' Critical Thinking Skills When Using a Multimedia Information System," Edith Cowan University, 1997.

[5] D. Sapitri dan A. Bentri, "Pengembangan Media Pembelajaran Berbasis Aplikasi Articulate Storyline pada Mata Pelajaran Ekonomi Kelas X,” Inovtech, vol. 02, no. 01, hal. 01-08, 2020.

[6] R. H. Ennis, A Logical Basis for Measuring Critical Thinking Skills. 1985.

[7] P. a. Facione, Critical Thinking: What It Is and Why It Counts, no. ISBN 13: 978-1-891557-07-1. 2011.

[8] A. A. S. S. Sari Dewi, “Teaching Learning Materials: The Reviews Coursebooks, Games, Worksheets, Audio Video Files,” Lingual J. Lang. Cult., vol. 2, no. 2, hal. 2-9, 2016, doi: 10.24843/ljlc.2016.v02.i02.p01.

[9] W. Bambang, Teknologi Pembelajaran Landasan dan Aplikasinya. Jakarta: Rineka Cipta, 2008.

[10] M. Sahana, "Critical Thinking: A Methodological tools for Geographical Research,” hal. 1-25, 2004.

[11] F. S. Yildirim dan S. A. Kiray, "Flipped classroom model in education,” Res. Highlights Educ. Sci., vol. 3, no. 5 S, hal. 1-8, 2016, doi: 10.24289/ijsser.348068.

[12] R. Simanjuntak, "Mengenal Teori-Teori Belajar," Sanctum Domine J. Teol., vol. 7, no. 1, hal. 47-60, 2020, doi: 10.46495/sdjt.v7i1.43.

[13] Panduan Kreatif Membuat Bahan Ajar Inovatif. Yogyakarta: Diva Press, 2015. 